Published as Alysia Blackham and Dominique Allen, 'Resolving Discrimination Claims outside the Courts: Alternative Dispute Resolution in Australia and the United

Kingdom' (2019) 31 Australian Journal of Labour Law 253-278.

\title{
RESOLVING DISCRIMINATION CLAIMS OUTSIDE THE COURTS: ALTERNATIVE DISPUTE RESOLUTION IN AUSTRALIA AND THE UNITED KINGDOM
}

\author{
Alysia Blackham* Dominique Allen**
}

\begin{abstract}
Alternative Dispute Resolution ('ADR') is a long-standing feature of both Australian and UK anti-discrimination law. In this article, we critically examine the advantages and disadvantages of using ADR to resolve a discrimination claim in Australia and the UK, and the effect ADR is having on discrimination law more broadly. While the UK and Australia have similar discrimination law statutes, and both largely rely on an individual rights model to address discrimination, they use ADR in contrasting ways, and with varying implications in practice. We argue that while ADR offers potential benefits in resolving discrimination claims, the extensive reliance on ADR in both jurisdictions to resolve disputes risks undermining the development of discrimination law. We offer five key areas in which the regulatory framework could be reviewed to address these limitations and risks.
\end{abstract}

\section{Introduction}

Alternative Dispute Resolution ('ADR') is a long-standing feature of both Australian and UK anti-discrimination law. Broadly, 'alternative dispute resolution' encompasses processes outside a formal court hearing in which a third party helps the parties to settle the matter. It can range from facilitative, where the third party's role is to help the parties discuss the matter and resolve it themselves, through to determinative, where the third party's role is to evaluate the dispute and make a decision. The various forms of ADR used in discrimination disputes are defined in Part 1.

In Australia federally and in all states and territories except one, it is compulsory for the parties to attempt to resolve a discrimination claim using ADR before proceeding to court. Statutory equal opportunity agencies are responsible for providing ADR services. Increasingly courts are subjecting cases to ADR in order to reduce their caseloads. Consequently, the vast majority of discrimination claims are resolved through ADR or withdrawn; very few proceed to a final hearing. In the UK, there is no compulsory ADR process for discrimination claims. However, the statutory body Acas (Advisory, Conciliation and Arbitration Service) offers both individual and collective conciliation, and mediation. Claimants are increasingly being directed towards Acas conciliation rather than the Employment Tribunal system: it is compulsory for claimants to notify Acas before lodging a Tribunal claim, though conciliation itself is not compulsory. 
In this article we critically examine the advantages and disadvantages of using ADR to resolve a discrimination claim in Australia and the UK, and consider the effect ADR is having on discrimination law. While both jurisdictions have similar discrimination law statutes, and both largely rely on an individual rights model to address discrimination, they use ADR in contrasting ways, and with varying implications. Thus, these jurisdictions are useful illustrations of the challenges and benefits of using ADR processes to resolve discrimination disputes. We argue that while ADR offers potential benefits in resolving discrimination claims, the extensive reliance on ADR in both jurisdictions risks undermining the development of discrimination law. In Part 1 we examine the potential attractions and limitations of $\mathrm{ADR}$, and consider why it has proliferated as a means of resolving employment discrimination disputes. In Part 2 we examine how ADR is used to resolve discrimination claims in Australia and the UK under the relevant anti-discrimination laws. Since 2010, the Fair Work Act 2009 (Cth) has also prohibited workplace discrimination and claims lodged under that Act can also be resolved through ADR conducted by the Fair Work Commission. However, there is very little academic literature about the Commission's ADR processes in the context of discrimination claims $^{1}$ and those statutory provisions vary greatly from both the UK and Australian anti-discrimination statutes. Thus, we do not consider ADR under the Fair Work Act. In Part 3 we discuss the theoretical challenges of using ADR to resolve legal disputes, particularly as they relate to discrimination law, and explore how these challenges are manifesting themselves in the context of discrimination claims. We conclude by identifying five key areas in which the regulatory framework should be reviewed to address the limitations and risks of ADR in the context of employment discrimination disputes.

\section{Part 1 - The Advantages and Disadvantages of Using ADR to Resolve Employment Discrimination Disputes}

ADR is used today in areas as diverse as commercial litigation, labour law, consumer law and tax law: it is offered as a matter of course by some courts and tribunals in an effort to help the parties avoid the time, stress and cost of litigation. In both Australia and the UK ADR has been a feature of anti-discrimination laws since their inception.

Part 2 explains the process of lodging and resolving a discrimination claim in both Australia and the UK, and defines the various ADR processes used in each. In order to identify the advantages and disadvantages of using ADR to resolve an employment discrimination dispute, it is necessary to explain what is meant by ADR in this context. In both Australia and the UK, the term 'ADR' refers to 'conciliation' and 'mediation'. In Australia, conciliation is provided by the statutory equal opportunity agency in each State and Territory and by the Australian Human Rights Commission

\footnotetext{
* Associate Professor, Melbourne Law School, University of Melbourne.

** Senior Lecturer, Department of Business Law and Taxation, Monash University.

An earlier version of this article was presented at the Berkeley Comparative Equality \& Anti-

Discrimination Law Study Group's annual conference in Shanghai, China in June 2016. We are grateful to participants for their comments and to the Journal's anonymous referees for their helpful feedback.

${ }^{1}$ On the use of ADR in resolving workplace disputes more broadly, see T MacDermott and J Riley, 'Alternative Dispute Resolution and Individual Workplace Rights: The Evolving Role of Fair Work Australia' (2011) 53 JIR 718; J Riley and T MacDermott, 'ADR and Industrial Tribunals: Innovations and Challenges in Resolving Individual Workplace Grievances' (2012) 38 Mon LR 82.
} 
('AHRC'); in the UK, it is offered by the statutory body Acas. Generally, this service is provided free of charge by staff conciliators either in person or by phone for the purposes of trying to settle the dispute. If the dispute does not settle and the employee chooses to litigate, claims can be subject to mediation conducted by courts or tribunals.

There are advantages to resolving a dispute using ADR rather than litigation, which explain its growth in popularity. ${ }^{2}$ Many of these reasons apply to all disputes, and not just employment or discrimination matters. ${ }^{3}$ In this section we consider the advantages and disadvantages of using ADR to resolve discrimination claims. As our focus is on employment discrimination claims, not every conclusion will apply to other types of disputes, though no doubt some will. We return to this in Part 3 to discuss what the use of ADR in resolving employment discrimination claims in Australia and the UK reveals about the pros and cons of ADR.

First, ADR is less expensive than litigation. Generally, in employment discrimination disputes, there is no cost to parties for participating in ADR: conciliation is provided for free by the statutory bodies involved. It is not necessary to have legal representation during this process, and there are none of the costs associated with litigation such as filing fees, expert witnesses, legal fees and the risk of paying the other side's costs. ${ }^{4}$

That said, as Astor and Chinkin note, it is difficult to quantify the cost of participating in ADR. Potential costs for both parties include the time spent away from employment, to brief lawyers, and to prepare for the ADR process itself. Further, ADR only saves costs if it actually settles the dispute. ${ }^{5}$

Second, ADR is much quicker than litigation. This is particularly important in employment disputes because relationships might be preserved if matters are attended to quickly. By contrast, litigation can be a long, drawn out process. There is usually a time lag between when the case is filed and heard by the court. However, as Dickens notes, the employment relationship is rarely preserved - in conciliation or litigation. ${ }^{6}$

Third, the lack of formality makes ADR less stressful than litigation. There is no need for the parties to give evidence or be cross-examined and they, rather than a judge, control the process. ${ }^{7}$ Astor and Chinkin argue that court rules about who may speak

\footnotetext{
${ }^{2}$ Of course, for some claimants the choice is not between ADR and litigation, but between ADR and not pursuing the claim at all. While acknowledging that the contrast between ADR and litigation is not so straightforward, we present the arguments in favour of ADR here by reference to the limitations of litigation, as these ideas were instrumental in the adoption of ADR processes in both jurisdictions.

${ }^{3}$ See generally H Astor and C M Chinkin, Dispute Resolution in Australia, Butterworths, Sydney, 1992, chap 2; M King et al, Non-Adversarial Justice, $2^{\text {nd }}$ edn, Federation Press, Annandale, 2014, chap 7.

${ }^{4}$ See, eg, Cavar v Greengate Management Services Pty Ltd [No.2] [2016] FCCA 3358 (22 December 2016) for an example of the costs that might be incurred in litigation.

${ }^{5}$ Astor and Chinkin, above $\mathrm{n} 3$, at pp 45-6.

${ }^{6}$ L Dickens, 'Employment Tribunals and Alternative Dispute Resolution' in L Dickens (Ed), Making Employment Rights Effective: Issues of Enforcement and Compliance, Hart Publishing, Oxford, 2012, p 29 at $\mathrm{p} 39$.

${ }^{7}$ D Allen, 'Behind the Conciliation Doors: Settling Discrimination Complaints in Victoria' (2009) 18 GLR 778 at 786.
} 
and when are quite remote from other aspects of social interaction. Thus, they "may provoke resentment" and may make participants feel "alienated from the proceedings". ${ }^{8}$ The informality of ADR means it is typically a less adversarial process than litigation, where the focus is not on winning but on negotiating an acceptable outcome, so relationships (which are central to the employment context) might survive intact.

Fourth, in discrimination claims ADR is a confidential process so the parties can negotiate freely, knowing that what is said cannot be used by the other side or subsequently if the matter goes to trial. ${ }^{9}$ Thornton writes that this benefits both employers, who would not be prepared to be labeled as wrongdoers in a public forum, and employees who may otherwise be deterred from lodging a complaint. ${ }^{10}$ Further, confidentiality creates a 'safe haven' where parties can express emotions and communicate their 'true interests', which might be lost in a court hearing. ${ }^{11}$ This means ADR is more likely to address parties' actual interests, and get to the core of a dispute.

Finally, ADR is more flexible both in terms of the process used and the outcome negotiated, enabling both to be tailored to the parties' individual circumstances.

Overall, then, by offering a less costly and quicker process than litigation, and one that puts the parties in control of the process, ADR is said to be attractive because it offers access to justice for those who would not otherwise use the legal system. Further, it is thought to be particularly appropriate where parties are in an ongoing relationship, as it will help to maintain relationships and avoid damaging the goodwill between the parties. ${ }^{12}$

However, there are significant disadvantages to resolving matters through ADR, particularly in employment relationships. First, ADR may actually reinforce the power imbalance between the employee and employer. The ADR process has been designed to ameliorate any power imbalances between the parties, through the intervention of a third party facilitator who is supposed to ensure that the process is fair and that each side has a chance to be heard. ${ }^{13}$ However, anecdotal concerns have been raised in the UK that, particularly in an era of budget cuts, ADR facilitators are becoming less skilled, and may lack the ability to moderate or ameliorate power balances. Further, vulnerable claimants may be confused or intimidated by the presence of an 'impartial' conciliator, resulting in feelings of powerlessness, ${ }^{14}$ or may

\footnotetext{
${ }^{8}$ Astor and Chinkin, above n 3, at p 35.

${ }^{9}$ See, eg, Equal Opportunity Act 2010 (Vic) s 117; Anti-Discrimination Act 1991 (Qld) s 164AA; Enterprise and Regulatory Reform Act 2013 (UK) c 24, s 10; Trade Union and Labour Relations (Consolidation) Act 1992 (UK) c 52, s 251B.

${ }^{10} \mathrm{M}$ Thornton, 'Equivocations of Conciliation: The Resolution of Discrimination Complaints in Australia' (1989) 52 MLR 733 at 740.

${ }^{11} \mathrm{G}$ R Clarke and I T Davies, 'Mediation - When Is It Not an Appropriate Dispute Resolution Process?' (1992) 3 ADRJ 70 at 74.

${ }^{12}$ K Mahoney, 'Mandatory Mediation: A Positive Development in Most Cases' (2014) 25 ADRJ 120 at 125.

${ }^{13}$ Clarke and Davies, above $\mathrm{n} 11$, at $73-4$.

${ }^{14} \mathrm{~N}$ Busby and M McDermont, 'Workers, Marginalised Voices and the Employment Tribunal System: Some Preliminary Findings' (2012) 41 ILJ 166 at 179; A Boon, P Urwin and V Karuk, 'What Difference Does it Make? Facilitative Judicial Mediation of Discrimination Cases in Employment
} 
feel that the conciliator is biased towards the employer. ${ }^{15}$ This may be aggravated by the increased use of telephone-based ADR and potential use of online ADR, ${ }^{16}$ where ADR facilitators have less opportunity to engage with the parties in any meaningful way, and non-verbal cues are missed or eliminated. ${ }^{17}$ As Clarke and Davies argue, a skilled mediator should reality test and challenge negotiated outcomes, such as to prevent the weaker party being 'railroaded' into an 'uninformed agreement'. ${ }^{18}$ Conciliators who are pressed for time, or rely solely on telephone contact with the parties, may be unable to generate enough trust and rapport with the parties to effectively fulfill this role. ${ }^{19}$ Further, power imbalances in ADR will be more apparent if the employer appoints a lawyer who engages in adversarial behaviour, particularly if the employee is unrepresented. ${ }^{20}$

The second concern is that ADR can only produce second class justice because the court, which is grounded in legal formalism and the rule of law, is the sole institution that can determine what is 'fair'. In this context, Thornton has expressed concerns that claimants may feel pressured to accept lesser remedies than they would at hearing. ${ }^{21}$ In a study of sexual harassment complaints in Queensland, Chase and Brewer found that while the women they interviewed settled their matter, external factors (such as the time and cost of litigation) forced them to do so and they generally did not feel that they obtained what they wanted from the ADR process, such as recognition of wrongdoing. ${ }^{22}$ Further, vulnerable claimants, who depend on law and legal rights to protect their interests, may be disadvantaged by the informality of mediation and conciliation. ${ }^{23}$ ADR can be used to re-frame disputes in a way that is less legal, and therefore potentially less intractable. ${ }^{24}$ This may significantly disadvantage vulnerable employees who lack the power to assert their needs. ${ }^{25}$

Third, the product of a successful ADR process is to settle the claim. This does not develop the law, as it denies the court an opportunity to interpret the law. ${ }^{26}$ The resultant 'erosion' of the doctrine of precedent represents the loss of a public good, and may undermine equality and justice in the legal system. ${ }^{27}$ While 'hard' cases are

\footnotetext{
Tribunals' (2011) 40 ILJ 45 at 78; M Hudson et al, Race Discrimination Claims: Unrepresented Claimants' and Employers' Views on Acas' Conciliation in Employment Tribunal Cases, Acas, Research Paper 04/07, 2007, at 10.

${ }^{15}$ Busby and McDermont, above n 14, at 180; Hudson et al, above n 14, at 80.

${ }^{16}$ M Legg, 'The Future of Dispute Resolution: Online ADR and Online Courts' (2016) 27 ADRJ 227.

${ }^{17} \mathrm{~J}$ S Wolfe, 'Across the Ripple of Time: The Future of Alternative (Or, Is It Appropriate) Dispute Resolution' (2001) 36 Tulsa LJ 785 at 803.

${ }^{18}$ Clarke and Davies, above n 11 , at 74 .

${ }^{19}$ Hudson et al, above $\mathrm{n} 14$, at 10-11.

${ }^{20}$ A Ardagh and G Cumes, 'Lawyers and Mediation: Beyond the Adversarial System?' (1998) 9 ADRJ 72 at 73.

${ }^{21}$ Thornton, 'Equivocations of Conciliation', above n 10, at 742.

${ }^{22} \mathrm{~T}$ Chase and M Brewer, 'Sexual Harassment in the Workplace and Conciliated Outcomes: Who Really Benefits?' (2009) 20 Labour \& Industry: A Journal of the Social and Economic Relations of Work 3 at 18.

${ }^{23}$ Busby and McDermont, above n 14, at 179.

${ }^{24} \mathrm{Ibid}$, at 179.

${ }^{25} \mathrm{Ibid}$, at 179 .

${ }^{26}$ D Allen, 'Against Settlement? Owen Fiss, ADR and Australian Discrimination Law' (2009) 10 IJDL 191 at 199-200.

${ }^{27} \mathrm{~J}$ Gruin, 'The Rule of Law, Adjudication and Hard Cases: The Effect of Alternative Dispute Resolution on the Doctrine of Precedent' (2008) 19 ADRJ 206 at 208. Of course, some of these cases may not have been brought at all without a system of ADR: at 211 . Thus, these arguments may be
} 
more appropriately the subject of adjudication than negotiation, they may be incidentally settled. ${ }^{28}$ Community legal centres in Victoria have expressed concern about the impact of ADR on public interest litigation, and on their ability to advocate for systemic change and law reform. ${ }^{29}$ Indeed, the body of case law that does develop may favour employers because they have the resources to challenge unfavourable decisions. ${ }^{30}$ Employers are typically, to use Galanter's terminology, 'repeat players' so they are interested in pursuing long-term interests, like rule change, and their interest extends beyond the outcome of any one claim. ${ }^{31}$ Employees may also be disinclined to risk litigating due to legal uncertainty and a lack of legal development.

'Alternative' dispute resolution can only ever be effective against the backbone of a primary, rights-based dispute resolution system, such as litigation. ${ }^{32}$ Thus, as we explore in Part 3, there is a need to ensure a sufficient flow of case law and litigation so ADR has an adequate legal and precedential basis to ensure equality and legal stability.

Finally, resolving claims through ADR denies the law an educative role, as claims are not reported and settlements are confidential. This may mean that potential claimants and respondents are not aware of what conduct is unlawful and the penalties for engaging in such behaviour. This limits a central aspect of the enforcement model, as we consider in Part 3. Further, the fact that disputes are resolved in a context separate from the workplace means that there is limited broader impact on the organisation concerned. ${ }^{33}$

Given the benefits and potential risks of ADR, the question is not so much whether to use ADR, but which discrimination claims should be resolved using ADR: when is ADR the 'appropriate' dispute resolution mechanism? ${ }^{34}$ Further, it is important to recognise the different types of ADR that are available, and the extent to which they might impact on the advantages and disadvantages. As Dickens argues, the distinction between these forms of ADR can be blurred, particularly the line between mediation and conciliation. ${ }^{35}$ Conciliation can be more like mediation, depending on the style of the conciliator, and can differ according to the setting - for example, in collective or individual conciliations. ${ }^{36} \mathrm{We}$ return to this consideration of when ADR will be appropriate in Part 3.

more an indictment of the system of litigation and issues of access to justice, than a critique of ADR as a system: at 211 .

${ }^{28} \mathrm{Ibid}$, at 211.

${ }^{29}$ L A Ojelabi, 'Community Legal Centres' Views on ADR as a Means of Improving Access to Justice - Part I' (2011) 22 ADRJ 111 at 115.

${ }^{30} \mathrm{See}$, eg, Gaze's discussion of this in the federal anti-discrimination jurisdiction: B Gaze, 'The Costs of Equal Opportunity' (2000) 25 Alt LJ 125 at 126.

${ }^{31}$ Indeed, Galanter says that one would expect the body of precedent cases to be skewed towards favouring repeat players. By contrast employees are 'one-shotters', so the stakes are much higher than for repeat players and they are most interested in the individual outcome of their claim than rule change: M Galanter, "Why the "Haves" Come Out Ahead: Speculations on the Limits of Legal Change' (1975) 3 Law \& Soc'y Rev 95 at 98-103.

${ }^{32}$ Wolfe, above $\mathrm{n} 17$, at 794 .

${ }^{33}$ Dickens, above $\mathrm{n} 6$, at 43.

${ }^{34}$ Wolfe, above $\mathrm{n} 17$, at 795 .

${ }^{35}$ Dickens, above n 6, at 40.

${ }^{36} \mathrm{Ibid}$, at 40. 


\section{Part 2 - The Use of ADR in Australia and the United Kingdom}

Given the potential benefits and challenges of using ADR, it is worth considering how $\mathrm{ADR}$ is used in Australia and the $\mathrm{UK}$ in relation to employment discrimination, and whether these issues have played out in practice. Part 2 provides an overview of how each jurisdiction uses ADR to contextualise our later discussion of the benefits, challenges and limitations of using ADR to resolve discrimination claims.

\section{A Australia}

ADR has been a feature of anti-discrimination legislation since it was introduced in the 1970s. ${ }^{37}$ Devereux writes that using ADR to resolve such disputes was in keeping with the 'private law' view of human rights. ${ }^{38}$ Frazer argues that ADR methods were adopted in discrimination law to achieve acceptance and change without 'provoking unnecessary confrontation', ${ }^{39}$ and were consistent with the legislation's aims of achieving gradual social change. ${ }^{40}$ Similarly, Gaze and Smith write that the rationale for compulsory ADR was that it would "promote reconciliation, cooperation, education, and respect for human rights." 41 Australia was also influenced by Canada, the UK and New Zealand's experience of using ADR to resolve discrimination claims. ${ }^{42}$

It is compulsory to undertake ADR before a court hearing in all jurisdictions except Victoria, where direct access to the tribunal was introduced in 2011.43 The legislation and enforcement process varies only slightly across the eight jurisdictions. As such, this article predominantly refers to the federal system.

A person who has experienced workplace discrimination can lodge a claim in writing at the AHRC. The claim will be referred to the AHRC President and, provided it has substance and falls within the AHRC's jurisdiction, the President must inquire into the claim and attempt to conciliate it. ${ }^{44}$ The Australian Human Rights Commission Act 1986 (Cth) does not define 'conciliation', and the provisions that deal with dispute resolution refer to a 'compulsory conference'. The Act also says very little about compulsory conferences, other than that they must be held at a reasonable time and at a reasonable place, ${ }^{45}$ in private and in a manner that does not disadvantage either party. ${ }^{46}$ In practice, the AHRC will inform the respondent that a claim has been made against it and seek a response. If the response alone does not settle the matter, the AHRC will attempt to facilitate a resolution between the parties.

\footnotetext{
${ }^{37}$ See, eg, the Racial Discrimination Act 1975 (Cth).

${ }^{38}$ A Devereux, 'Human Rights by Agreement? A Case Study of the Human Rights and Equal Opportunity Commissions' Use of Conciliation' [1996] ADRJ 280 at 282.

39 A Frazer, 'Anti-Discrimination Law at Mid-Life Crisis' (2011) 24 AJLL 75 at 77.

${ }^{40} \mathrm{Ibid}$, at 90.

${ }^{41}$ B Gaze and B Smith, Equality and Discrimination Law in Australia: An Introduction, Cambridge University Press, Port Melbourne, 2016, p 176.

${ }^{42}$ Devereux, above $\mathrm{n} 38$.

${ }^{43}$ Equal Opportunity Act 2010 (Vic) s 122.

${ }^{44}$ Australian Human Rights Commission Act 1986 (Cth) (AHRC Act) ss 46P, 46PF, 46PH.

${ }^{45}$ AHRC Act s 46PJ(2).

${ }^{46}$ AHRC Act s 46PJ(2), (3).
} 
The AHRC resolves complaints using 'conciliation', which it says is a process through which "people involved in a complaint talk through the issues with the help of someone impartial and settle the matter on their own terms." 47 The process is confidential, ${ }^{48}$ as are the terms of settlement. The AHRC does not publish any information about the nature of the complaints or how they were resolved other than de-identified case studies in its annual reports ${ }^{49}$ and on its website. ${ }^{50}$

If the claim cannot be resolved, the claimant can lodge their claim in the federal courts. It may then undergo what the Federal Court terms 'assisted dispute resolution'. One method the Court uses is mediation, which is conducted by a court registrar who is also an accredited mediator. The Court says mediation is a "routine way" it facilitates the "quick, inexpensive and efficient resolution of disputes". 51

The vast majority of discrimination claims are resolved using ADR (either by the AHRC or the federal courts) or withdrawn; very few are resolved through a court hearing. This 'funneling' effect is shown in Table 1.

Table 1: Comparison of Discrimination Claims in Australia, 2014-15 ${ }^{52}$

\begin{tabular}{|l|l|l|}
\hline & Federal & Victoria \\
\hline Claims received conciliated by the & 83803 & 1,060 \\
\hline $\begin{array}{l}\text { Claims successfully } \\
\text { agency }\end{array}$ & $72 \%$ & Not reported \\
\hline $\begin{array}{l}\text { Complaints } \\
\text { resolved through ADR }\end{array}$ & $69.4 \%$ \\
\hline Claims lodged at court & 87 in the FCCA & $223^{53}$ \\
\hline Mediations & $\begin{array}{l}43 \text { in the FCCA } 17 \\
\text { in the FCA }\end{array}$ & Not reported \\
\hline Successful mediation rate & $67 \%$ in the FCCA & $70 \% 55$ \\
\hline
\end{tabular}

47 Australian Human Rights Commission, Complaint Information, at $<$ https://www.humanrights.gov.au/complaint-information> (accessed 11 September 2017).

${ }^{48}$ Some Acts state specifically that if the claim proceeds to the tribunal, anything said during the dispute resolution process is not admissible in those proceedings: see eg Equal Opportunity Act 2010 (Vic) s 117; Anti-Discrimination Act 1991 (Qld) s 164AA; Equal Opportunity Act 1984 (SA) s 95(9).

${ }^{49}$ Australian Human Rights Commission, Annual Report 2014-2015, Australian Human Rights Commission, Sydney, 2015, at 34, 37, 60 .

${ }^{50}$ See, eg, Australian Human Rights Commission, Case Studies - Conciliated Complaints of Discrimination in Employment, at <https://www.humanrights.gov.au/case-studies-conciliatedcomplaints-discrimination-employment $>$ (accessed 11 September 2017).

${ }^{51}$ Federal Court of Australia, Annual Report 2014-2015, Federal Court of Australia, 2015, at 31.

${ }^{52}$ Although the agencies may break down the data according to whether the complaints it received related to employment or not, they do not do this in relation to the conciliations they conducted or their outcomes. The tribunals do not breakdown complaints in this way at all. Thus for ease of comparison, both employment and non-employment complaints are included in Table 1. Data is from the following sources: Australian Human Rights Commission, 'Annual Report 2014-2015', above n 49, at 142-3, 145-6, 148, 150, 152-3; Federal Court of Australia, above n 51, at Table 3.6, Table A5.12; Victorian Equal Opportunity and Human Rights Commission, Victorian Equal Opportunity and Human Rights Commission Annual Report 2014/15, Victorian Equal Opportunity and Human Rights Commission, Melbourne, 2015, at 20-22; Federal Circuit Court of Australia, Annual Report 2014-2015, Federal Circuit Court of Australia, 2015, at Table 3.5, Table 3.8; Victorian Civil and Administrative Tribunal, Annual Report 2014-15, Victorian Civil and Administrative Tribunal, 2015, at 34.

${ }^{53}$ The tribunal does not break down the data, so this includes employment and non-employment discrimination claims as well as applications for exemptions from the Act.

${ }^{54}$ This, however, is the number of 'human rights' matters referred to mediation which is broader than just 'anti-discrimination' matters, as it includes Div 3 Part II of the AHRC Act. 


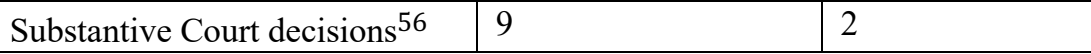

\section{$B \quad$ The United Kingdom}

Conciliation has been at the core of the UK discrimination law framework since its inception. Prior to the founding of Acas, legislation prohibiting racial discrimination in public life was enforced via complaints to the Race Relations Board. ${ }^{57}$ The Board or a conciliation committee would 'investigate' complaints, including by making inquiries and attempting to secure a settlement. ${ }^{58}$ If the Board concluded that the act was unlawful, and a settlement could not be reached, or the act was done in breach of an assurance not to repeat a discriminatory action, the Board could bring civil proceedings. ${ }^{59}$ For employment complaints, however, a different structure was established: 60 complaints were made or referred to the Secretary of State for Employment and Productivity, who would then refer the complaint for investigation to a 'suitable' body of persons or to the Board. ${ }^{61}$ The use of a 'body of persons' in this context opens up the possibility of using industrial dispute procedures to resolve discrimination complaints. While the 'body of persons' had similar duties to the Board in investigating complaints, they had an additional duty to report to the Secretary of State for Employment and Productivity, and matters could be referred to the Board for investigation or pursued in civil proceedings in some instances. ${ }^{62}$

Acas was founded in 1974 to provide independent conciliation in employment disputes. ${ }^{63}$ When sex discrimination legislation was introduced in $1975,{ }^{64}$ claimants were given direct access to industrial tribunals (for employment claims) ${ }^{65}$ or county courts. ${ }^{66}$ Where a copy of a complaint to an industrial tribunal was sent to a conciliation officer, the officer had a duty 'to endeavor to promote a settlement of the complaint without its being determined by an industrial tribunal' where requested by both parties, or if the officer considered that they could promote a settlement 'with a reasonable prospect of success' ${ }^{67}$ These provisions were replicated in the Race Relations Act 1976 (UK) c 74 to provide for direct access for individual race discrimination claimants to industrial tribunals. ${ }^{68}$ Thus, the prospect of conciliation has been instrumental in the development of discrimination regimes in the UK.

Most discrimination claims arise in the context of employment, and are heard by Employment Tribunals ('ET'). ETs are independent judicial bodies, which are

\footnotetext{
${ }^{55}$ Of those claims, over $70 \%$ were resolved either through the ADR process or before hearing: Victorian Civil and Administrative Tribunal, above n 52, at 34.

${ }^{56}$ Excluding applications made for exemptions and procedural hearings such as strike out claims or costs orders.

${ }^{57}$ Race Relations Act 1965 (UK) c 73, s 2; Race Relations Act 1968 (UK) c 71, s 14.

${ }^{58}$ Race Relations Act 1968 (UK) c 71, s 15(3).

${ }^{59}$ Ibid, ss 15(4)-(5), 19, 20.

${ }^{60}$ Ibid, s 16 .

${ }^{61} \mathrm{Ibid}, \mathrm{sch} 2$.

62 Ibid, sch 2.

${ }^{63}$ Employment Protection Act 1975 (UK) c 1 ss 2, 126(1); Trade Union and Labour Relations Act 1974 (UK) c 52, s 29.

${ }^{64}$ Sex Discrimination Act 1975 (UK) c 65.

${ }^{65}$ Ibid, s 63.

${ }^{66}$ Ibid, s 66.

${ }^{67}$ Race Relations Act 1976 (UK) c 74, s 55(1).

${ }^{68}$ Ibid, ss 54, 55(1).
} 
intended to provide a less formalised, more efficient and less costly means of resolving employment claims than court proceedings. ${ }^{69}$ As Dickens notes, the ETs themselves were therefore originally seen as an alternative form of dispute resolution. ${ }^{70}$ However, the Gibbons review in 2007 found tribunals to be 'too costly and complex', with an 'excessive' focus on procedure. ${ }^{71}$ ADR, particularly in the form of mediation, was seen as an effective alternative to facilitate the early resolution of disputes. ${ }^{72}$ To complement the ET system, then, Acas offers individual and collective conciliation and mediation to attempt to resolve disputes while avoiding the potential cost, time and stress of the tribunal system.

The use of ADR, while always pertinent in the UK, is becoming even more instrumental with the introduction of Acas early conciliation. Until 2014, Acas offered 'pre-claim conciliation', which was a voluntary conciliation process for all claims relating to employment conducted before a claim was submitted to an ET. Acas describes its conciliation process as follows:

Conciliation involves an independent Acas conciliator who discusses the issues with both parties in order to help them reach a better understanding of each other's position and underlying interests. Without taking sides, the conciliator tries to encourage the parties in a dispute to come to an agreement between themselves. ${ }^{73}$

Acas promotes seven key features of its conciliation process:

1. It is voluntary.

2. The parties are in control, including in determining the outcome, which is more flexible than in ET proceedings.

3. It informs.

4. It saves time and money.

5. Acas is impartial and independent.

6. It is confidential, and discussions are not admissible in ET proceedings.

7. It can restore trust. ${ }^{74}$

In April 2014, Acas started providing early conciliation rather than pre-claim conciliation. The major difference between the two systems is that since May 2014, employees must contact Acas before making a claim to an ET. ${ }^{75}$ Acas must offer

\footnotetext{
${ }^{69}$ Acas, Employment Tribunals, at $<$ http://www.acas.org.uk/index.aspx?articleid=1889> (accessed 11 September 2017).

${ }^{70}$ Dickens, above n 6, at p 31.

${ }^{71}$ M Gibbons, Better Dispute Resolution: A Review of Employement Dispute Resolution in Great

Britain, Department of Trade and Industry, 2007, at 8.

72 Ibid, at 9 .

73 Acas, Conciliation Explained, Acas, March 2015, at $<$ http://www.acas.org.uk/media/pdf/c/1/Conciliation-Explained-Acas.pdf $>$ (accessed 11 September 2017), at 4.

${ }^{74} \mathrm{Ibid}$, at $4-5$.

${ }^{75}$ Enterprise and Regulatory Reform Act 2013 (UK) c 24 s 7; The Employment Tribunals (Early Conciliation: Exemptions and Rules of Procedure) Regulations 2014 (UK) SI 254/2014. Individuals do not need to notify Acas of their intention to make a claim where: another person has complied with the requirement in relation to the same dispute; Acas does not have a duty to conciliate on some or all of the claim; the employer has already contacted Acas; the claim is for unfair dismissal, and the claimant intends to apply for interim relief; or the claim is against the Security Service, Secret Intelligence
} 
early conciliation for up to one calendar month after it is notified of an intention to make a claim. ${ }^{76}$ This period may be extended for up to two weeks with the parties' agreement. ${ }^{77}$ Acas conciliation is also available after a tribunal claim has been lodged, up until a judgment is handed down.

Following the move to early conciliation, in 2014-15 Acas received 83,000 early conciliation notifications: 73 per cent of notifications proceeded to conciliation, and 78 per cent of notifications did not lead to a Tribunal claim. ${ }^{78}$ Only 10 per cent of claimants and 11 per cent of employers did not agree to participate in conciliation. ${ }^{79}$ Fifteen per cent of notifications (11,000 claims) led to a formal settlement following ADR, and 10 per cent were resolved without a formal written agreement. ${ }^{80}$ Similar results were obtained in 2015-16, as illustrated by Table 2 .

Table 2: Early conciliation statistics for Acas, April 2015 to March $2016^{81}$

\begin{tabular}{|c|l|}
\hline Early conciliation notifications & \multicolumn{1}{|c|}{ Number } \\
\hline Employee & 87,892 \\
\hline Employer & 4,280 \\
\hline Total & 92,172 \\
\hline Formal settlement & $\mathbf{1 5 , 4 2 0}(\mathbf{1 7 \%})$ \\
\hline Not progressed to Tribunal claim & $\mathbf{5 9 , 2 9 5 ( 6 5 \% )}$ \\
\hline Progressed to Tribunal claim & $\mathbf{1 6 , 8 7 0 ( 1 8 \% )}$ \\
\hline Formal settlement after filing claim & $5,651(33 \%)$ \\
\hline Withdrawn & $1,480(9 \%)$ \\
\hline Determined by ET & $2,487(15 \%)$ \\
\hline In progress & $7,252(43 \%)$ \\
\hline
\end{tabular}

These statistics imply that early conciliation and post-claim conciliation are redirecting the vast majority of claims away from the tribunal system. While numbers of notifications and claims resolved may represent different cases (as some claims remain unresolved at the start of the statistical period), around 3 per cent of notifications are actually proceeding to an ET determination. This is much higher than in Australia, where the figure is around 0.5 per cent in the federal jurisdiction.

However, few claims are actually achieving some sort of formal resolution via conciliation. Thus, many claims appear to be abandoned at some stage during the ADR process. This may be the result of the educative function of ADR, as claimants realise that their claim lacks merit through the conciliation process, or may merely mean that additional hurdles to making a claim are deterring claimants from

Service or GCHQ: The Employment Tribunals (Early Conciliation: Exemptions and Rules of Procedure) Regulations 2014 (UK) SI 254/2014 reg 3.

76 The Employment Tribunals (Early Conciliation: Exemptions and Rules of Procedure) Regulations 2014 (UK) SI 254/2014 sch 1, reg 6(1).

${ }^{77}$ Ibid, sch 1, reg 6(2)-(3).

${ }^{78}$ Acas, Advisory, Conciliation and Arbitration Service (Acas) Annual Report and Accounts 2014/15, Acas, HC 282, Stationery Office, 2015, at 12.

${ }^{79}$ Ibid.

${ }^{80}$ Ibid.

81 Acas, Early Conciliation Update 7: April 2015 - March 2016, Acas, 23 May 2016, at $<$ http://www.acas.org.uk/index.aspx?articleid=5741> (accessed 11 September 2017), at 7. 
proceeding. Alternatively, parties may be achieving an informal resolution to their claims.

Overall, early conciliation appears to be reducing demands on the tribunal system in the UK. However, this must be seen in the context of broader reforms to the ET system. From 29 July 2013 to 26 July 2017, ETs charged substantial fees to hear claims or appeals. ${ }^{82}$ The fee regime significantly deterred applicants in practice: from October to December 2013, ETs received 79 per cent fewer claims compared with the same period in 2012, and 75 per cent fewer claims than in the previous quarter. ${ }^{83}$ These challenges were compounded by government austerity measures, which generally excluded legal aid funding for employment matters. ${ }^{84}$ The substantial impact of fees on claiming behaviour is reflected in the first year conciliation statistics: of the 63 per cent of claimants who did not proceed to a tribunal claim, but who failed to achieve a settlement, 26 per cent indicated that tribunal fees deterred them from proceeding with their claim. ${ }^{85}$ Thus, early conciliation is far from the only factor reducing the caseload of tribunals. Recognising the significant potential of Tribunal fees to inhibit access to justice, the UK Supreme Court found the fees regime to be unlawful in $R$ (Unison) $v$ Lord Chancellor, ${ }^{86}$ and quashed the Employment Tribunals and Employment Appeal Tribunal Fees Order 2013. Tribunals are now refusing to accept fees from claimants. ${ }^{87}$ This may significantly increase the number of claims proceeding to Tribunal.

As Dickens argues, the push towards ADR as an alternative to the tribunal system has largely focused on reducing demands on ETs and minimising the cost of dispute resolution. Thus, 'success' of ADR is measured by how many claims are redirected away from the tribunal system. This way of conceiving ADR, and its 'success', undermines the potential use of ADR to make employment rights effective in practice, and achieve fairness in the workplace. ${ }^{88}$ Rather than focus on dispute resolution, conciliation now emphasises claim disposal. ${ }^{89}$

While conciliation is still voluntary (and a minority of claimants and respondents refuse to participate), the requirement to notify Acas of an intention to lodge an ET claim is likely to lead to much higher levels of conciliation prior to proceeding to a tribunal. It is also noteworthy that in the first year survey of claimants who had notified Acas of their claims, 30 per cent participated in conciliation because they thought it was compulsory, ${ }^{90}$ even though it is technically voluntary. ${ }^{91}$ Thus, there

\footnotetext{
${ }^{82}$ HM Courts \& Tribunals Service, Employment Tribunal Fees for Individuals, HM Courts \& Tribunals Service, T435, November 2013.

${ }^{83}$ Ministry of Justice, Tribunals Statistics Quarterly: October to December 2013, Ministry of Justice, 13 March 2014, at 8.

${ }^{84}$ See Legal Aid, Sentencing and Punishment of Offenders Act 2012 (UK) c 10, sch 1, pt 1, s 43.

${ }^{85} \mathrm{M}$ Downer et al, Evaluation of Acas Early Conciliation 2015, Acas, Research Paper 04/15, 2015, at 97.

86 [2017] 3 WLR 409; [2017] UKSC 51.

87 GOV.UK, Make a Claim to an Employment Tribunal, GOV.UK, at $<$ https://www.gov.uk/employment-tribunals/make-a-claim> (accessed 11 September 2017).

${ }^{88}$ Dickens, above n 6, at p 32.

${ }^{89} \mathrm{Ibid}$, at $\mathrm{p} 44$.

${ }^{90}$ Downer et al, 'Evaluation of Acas Early Conciliation 2015', above n 85, at 5.

${ }^{91}$ Similarly, since Victoria introduced optional agency conciliation in 2011, most claimants have continued to utilise it, rather than lodging directly at the tribunal. It is not known how many were not aware that conciliation is no longer compulsory.
} 
appears to be a fine line between compulsory notification (as in the UK) and compulsory conciliation (as in Australia). This appears to undermine individual consent to the process.

\section{Part 3 - Benefits, Challenges and Limitations of Using ADR to Resolve Discrimination Claims}

While there are certainly benefits in using ADR, particularly in jurisdictions in which claimants are often disadvantaged, due to the time, cost and formality of litigation, there are also drawbacks, including for the development of substantive law and in achieving broader social change. In this Part, we explore what the practice of ADR in both countries reveals about the benefits, limitations and challenges of using ADR to resolve discrimination disputes in particular. In the final part of this article, we propose five ways the current system could be strengthened to overcome the weaknesses we identify in the regulatory model.

\section{A Expedient Process}

One of the attractions of ADR identified in Part 1 is that it is a far quicker way of obtaining an outcome than litigation. This is indeed the case for discrimination claims. The AHRC states that its goal is to finalise 80 per cent of complaints within 12 months of receipt. In 2014-15, 99 per cent of complaints were finalised within 12 months and the average time from lodgment to finalisation was approximately 3.7 months. ${ }^{92}$ By contrast, Australia's most recent superior court decision about employment discrimination took 11 years to resolve from the time the claim was lodged at the statutory equal opportunity agency to being heard by the High Court. ${ }^{93}$ Even if ADR does not lead to a settlement, the process may narrow the issues in dispute, which means the full hearing will take less time and perhaps cost less.

Claimants and respondents may also spend less time on the claim by using ADR. Acas claimants spent on average 27 hours on the dispute, and the median time was six hours. ${ }^{94}$ This compares to an average of 30 days for ET applications, and a median of six days. ${ }^{95}$ For respondents, the average time spent on conciliated matters was 15 hours, with a median of 5 hours; this compares with an average of 13 working days and median of 5 working days for ET applications. ${ }^{96}$ Thus, conciliation may be less time consuming than litigation, and resolve matters more expeditiously.

\section{B Cost}

The cost of litigation is a significant factor driving parties to attempt to resolve a claim through ADR. This is particularly so for employees in discrimination matters who are often from marginalised groups or who would not be able to afford legal representation. A survey of participants in the AHRC's conciliation process revealed

\footnotetext{
92 Australian Human Rights Commission, 'Annual Report 2014-2015', above n 49, at 72. Similarly, the statutory equal opportunity agency in Victoria states that in 2014-15, 86 per cent of its complaint files were closed within six months of receipt: Victorian Equal Opportunity and Human Rights Commission, above n 52, at 7. Some jurisdictions impose time limits in which the equal opportunity agency must handle the claim: see, eg, Anti-Discrimination Act 1991 (Qld) s 141.

${ }_{93}^{3}$ New South Wales v Amery (2006) 230 CLR 174; 226 ALR 196; [2006] HCA 14.

${ }^{94}$ Downer et al, 'Evaluation of Acas Early Conciliation 2015', above n 85, at 59.

95 Ibid, at 60 .

${ }^{96}$ Ibid, at 60-1.
} 
that the time and cost of litigation were a reason for settling prior to court. ${ }^{97}$ There is no cost for attempting ADR unless the claimant briefs a lawyer, but they often choose not to. ${ }^{98}$ In a study about using ADR to resolve discrimination claims in Queensland, Allen found that two thirds of claimants had legal representation at hearing, while less than 50 per cent did at mediation. ${ }^{99}$ Similarly, the AHRC reports that in 2014-15, of the 37 per cent of claimants who had representation at the beginning of the complaint resolution process, only 39 per cent of them were represented by a privately funded solicitor (that is, 14 per cent overall). ${ }^{100}$ The remainder were represented by a mix of groups which may have been subsidised or cost free, including community legal centres (18 per cent) and trade unions or professional associations ( 4 per cent). This still shows that a significant number of claimants considered it to be necessary to have advice during the conciliation process. ${ }^{101}$ Therefore, while it may be less costly to pursue ADR than litigation, and legal representation is not strictly required, in practice many claimants prefer to have some form of advice or assistance through the ADR process.

Similar findings have emerged from the UK. In the first year statistics, 24 per cent of claimants used a representative in conciliation, ${ }^{102}$ compared with 29 per cent of employers. ${ }^{103}$ For 43 per cent of claimants with a representative (or 10 per cent of claimants overall), this person was a solicitor, barrister or some other kind of lawyer ${ }^{104}$ compared with 55 per cent (or 16 per cent overall) for employers. ${ }^{105}$ Like in Australia, this rate of representation was lower than for ET claims generally: the Survey of Employment Tribunal Applications 2013 found that 52 per cent of claimants in Tribunals had representation. ${ }^{106}$

Overall, ADR will not cost as much as litigation even for claimants who do engage legal representation - the cost of representing the claimant at ADR will be far cheaper than for a hearing, particularly given the shorter time period usually spent on claims. ADR is also less costly than litigation because the claimant does not incur the associated costs such as engaging barristers, seeking expert witnesses and court filing fees. Nor do they risk a costs order being imposed on them if they lose. ${ }^{107}$ Thus, for

\footnotetext{
${ }^{97}$ T Raymond and S Georgalis, Dispute Resolution in the Changing Shadow of the Law: A Study of Parties' Views on the Conciliation Process in Federal Anti-Discrimination Law, Human Rights and Equal Opportunity Commission, 2002. Gaze and Hunter found the same in their study of the federal system in which they surveyed parties to claims: B Gaze and R Hunter, Enforcing Human Rights in Australia: An Evaluation of the New Regime, Themis Press, Sydney, 2010, chap 4. Allen also identified these reasons in her study of Victoria, though this was based on the views of lawyers, legal representatives and agency staff, not participants: Allen, 'Behind the Conciliation Doors', above $\mathrm{n} 7$.

${ }^{98}$ In the federal jurisdiction, parties cannot be represented as of right but must seek the consent of the person presiding over the compulsory conference: AHRC Act, s 46PK(5). See also Anti-Discrimination Act 1977 (NSW) s 91B.

${ }^{99}$ D Allen, 'Removing Barriers to Substantive Equality: A Case Study of Remedying Disability Discrimination Complaints' (2011) 17 AJHR 159 at 171.

${ }^{100}$ Australian Human Rights Commission, ‘Annual Report 2014-2015', above n 49, at 137.

${ }^{101}$ Ibid.

${ }^{102}$ Downer et al, 'Evaluation of Acas Early Conciliation 2015', above n 85, at 25.

${ }^{103} \mathrm{Ibid}$, at 28 .

${ }^{104} \mathrm{Ibid}$, at 25 .

${ }^{105} \mathrm{Ibid}$, at 28 .

${ }^{106}$ Ibid, at 25 .

${ }^{107}$ Both the Federal Court and Federal Circuit Court have the power to award costs in discrimination claims. In determining the appropriate amount to award, the judge can take into account a settlement offer which was rejected: AHRC Act, s 46PSA.
} 
claimants who may be vulnerable or financially constrained, ADR offers a desirable alternative to pursuing a discrimination claim in the courts.

\section{Confidentiality}

The confidentiality of the ADR process itself and its outcomes is both a benefit and a limitation of ADR. It is advantageous because it means that the parties can negotiate freely, knowing that if they do not settle the claim, the other party cannot use what was said in court proceedings. However, confidentiality is also one of the main limitations of ADR: given the process and outcomes are confidential, it is difficult to evaluate whether the law is achieving its purpose, both in remedying the individual situation and in achieving broader, systemic outcomes. It is difficult for ADR to have any influence on legal norms and the development of legal standards when the outcomes of claims are hidden. ${ }^{108}$ This is made more difficult by the fact that Australian equal opportunity agencies release very little data about the outcomes obtained at settlement or about the parties' satisfaction with the process itself. This means that later conciliation participants do not have access to information about the process and possible settlement outcomes, which might disadvantage unrepresented claimants. ${ }^{109}$ Confidentiality also masks the extent to which discrimination remains a problem in society. Very few cases reach the courts each year in Australia, as shown above in Table 1. Most cases are settled, so the community is not made aware that discrimination still exists, the forms it takes, its frequency or how it is being addressed. This seriously impedes discrimination law's educative role and function, and its ability to address structural or systemic discrimination. Thus, for Thornton, ' $[\mathrm{t}]$ he atomism inherent within the confidential conciliation process underscores the notion that acts of discrimination are of an isolated and individualistic nature and that individualistic solutions alone are appropriate.' 110 This is replicated in the remedies obtained through conciliation (discussed below). For Thornton, then, conciliation also reinforces the public/private divide in liberal societies, ${ }^{111}$ with discrimination being seen as something that is private and should be addressed behind closed doors. This, then, undermines the objective of discrimination law: to promote the participation of all groups in public life.

These concerns play out in the UK's system of confidential conciliation. Indeed, in the employment context, a renewed focus on ADR has been seen as a means of privatising the enforcement of employment rights. ${ }^{12}$ In this model of confidential conciliation, "neither deliberations nor the outcome are made public, diminishing the diffusion of best practice usually derived from public hearings.' ${ }^{113}$ However, Acas publishes slightly more information about conciliation claims and outcomes than the equal opportunity agencies in Australia. Drawing on the first year statistics from the UK's early conciliation process, it is possible to make some preliminary conclusions

\footnotetext{
${ }^{108}$ See generally O Fiss, 'Against Settlement' (1984) 93 Yale LJ 1073.

109 The equal opportunity agency's existence is supposed to ameliorate this disadvantage, however, as a neutral participate the commission cannot support or advocate for the claimant.

${ }^{110}$ M Thornton, The Liberal Promise: Anti-Discrimination Legislation in Australia, Oxford University Press, Melbourne, 1990, p 151.

${ }^{111}$ M Thornton, 'The Public/Private Dichotomy: Gendered and Discriminatory' (1991) 18 J L \& Soc 448 at 450.

${ }^{112}$ A Pollert, 'The Unorganised Worker: The Decline in Collectivism and New Hurdles to Individual Employment Rights' (2005) 34 ILJ 217 at 226-7; T Colling, 'No Claim, No Pain? The Privatization of Dispute Resolution in Britain' (2004) 25 Economic and Industrial Democracy 555.

${ }^{113}$ Colling, above n 112, at 558.
} 
regarding the impact of early conciliation on claim outcomes in the UK. While most conciliation participants ( 83 per cent) were satisfied with the conciliation process generally, not many were satisfied with the actual outcomes achieved (especially claimants). Only 48 per cent of claimants and their representatives, 65 per cent of employers and their representatives, and 57 per cent of participants overall reported satisfaction with the actual outcomes of conciliation. ${ }^{114}$ Even with improved reporting by Acas, little is known about the nature of the claims received, the details of the discriminatory behaviour, or how generalised statistics relate to discrimination claims. Further, it is unlikely that Acas will replicate the study of first year participants in later years (and has not yet done so). Thus, the data that is available may become stale quickly.

\section{Remedies}

There is no limit to the terms of settlement when a claim is resolved through ADR, so theoretically the parties can agree to anything. This could include systemic or creative remedies, which courts are unable or typically unwilling to award. ${ }^{115}$ Thus, ADR could be a useful mechanism for addressing structural discrimination, and changing organisational behaviour and practice. However, a criticism of ADR is that there is no guarantee that it protects the public's interest in eliminating discrimination (such as through systemic remedies) or that it protects individual rights through individual remedies. ${ }^{116}$ This is particularly problematic if courts use ADR purely as a case management technique in an effort to prevent too many claims from swamping an already busy court system: the focus then turns to reaching a settlement, rather than what the settlement is. Indeed, Acas's key performance indicators include: 'The promotion of a settlement in disputes in which is Acas is involved.' 117 There is no mention of the quality of settlements in Acas's KPIs. For Thornton, this reflects the nature of ADR as a bureaucratic phenomenon, which focuses on 'efficiency measured by the number of complaints resolved.' 118

In Australia it is not possible to rigorously examine the terms of settlement due to confidentiality clauses in settlement agreements and the lack of data released by the equal opportunity agencies. However, in a study of the outcomes negotiated in discrimination complaints settled in Queensland, Allen found that parties did sometimes agree to terms that courts were unlikely to order - such as wider, systemic remedies - but this was not the norm. Agreements negotiated at conciliation most often included an individualised remedy, usually compensation (61 per cent), an apology (49 per cent) or a reference ( 26 per cent). Sexual harassment complaints were the most common types of claims that settled with a systemic remedy, but that was usually training or requiring the employer to review its policies and practices. In the one year period Allen examined, no employment claims settled with changes to

\footnotetext{
${ }^{114}$ Downer et al, 'Evaluation of Acas Early Conciliation 2015', above n 85, at 7.

${ }^{115}$ While ETs used to be able to make broader recommendations to address systemic issues and discriminatory practices, that power has now been limited to making recommendations related to the claimant: Deregulation Act 2015 (UK) c 20, s 2. Thus, the capacity of UK tribunals to award systemic remedies has been limited. See also Galanter who suggests that courts may not be of use to the 'havenots' because they cannot make the kind of orders that would be most useful to them: Galanter, above n 31, at 137.

${ }^{116}$ Fiss, above $\mathrm{n} 108$.

117 Acas, Advisory, Conciliation and Arbitration Service (Acas) Annual Report and Accounts 2015/16, Acas, HC 550, Stationery Office, 2016, at 34.

118 Thornton, The Liberal Promise, above n 110, at $\mathrm{p} 148$.
} 
access for a person with a disability. Similarly, in tribunal mediation, systemic outcomes were rare. ${ }^{119}$

More can be said about the UK, where Acas has released some information about settlements achieved through conciliation. The vast majority of Acas settlements (91 per cent) reached in the first year of early conciliation involved financial compensation, and some involved a reference ( 25 per cent) and/or an apology ( 4 per cent). ${ }^{120}$ There was no mention in the statistics of claimants achieving systemic change as a result of the ADR process. While the majority of claimants reported receiving financial compensation as part of their settlement, the size of payments varied considerably, with the median sum of money received being $£ 1,200$, and with payments ranging from $£ 12$ to $£ 100,000$ (though with the majority being at the lower end). ${ }^{121}$ At the same time, 96 per cent of claimants and their representatives who received a financial payment as part of their settlement confirmed that it had been paid; this statistic is much higher than at the tribunal, where only 63 per cent said that they had received their payment. ${ }^{122}$ Thus, while payments may be low, they are at least paid.

Similar results were found in the Acas survey of conciliation after an ET claim had been filed. Among these settlements (both formal and informal), claimants reported receiving money in 86 per cent of cases, and a reference in 28 per cent of cases. Claimants who received money reported an average amount of $£ 10,067$, though amounts ranged from $£ 84$ to $£ 94,000$, with a median of $£ 5,422 .{ }^{123}$ On average, the amount reported was higher than for claimants in early claim conciliation. ${ }^{124}$

Overall, then, while ADR offers parties the opportunity to tailor their own solutions to discrimination claims, this appears to be happening in only a minority of cases in both jurisdictions. The vast majority of claims lead to outcomes that are also achievable in courts and tribunals, and largely focus on financial compensation.

Of course, simply participating in the ADR process could be seen as a form of remedy in itself. Menkel-Meadow has argued that settlement processes that include more participation by the parties may facilitate greater participation in the legal system than the formal court system. By allowing conversation and confrontation, such a process may be richer than the traditional adversarial system. ${ }^{125}$ She writes that settling a dispute can be justified on moral grounds because it is consistent with values such as consent, participation, empowerment, dignity, respect, empathy, equity and access which underpin our legal system. ${ }^{126}$ The ADR process may therefore offer a benefit to the claimant, in allowing them to tell their story in their own words and be listened to by the respondent. Allen identified that for some claimants, simply talking about their

\footnotetext{
${ }^{119}$ D Allen, 'In Defence of Settlement: Resolving Discrimination Complaints by Agreement' (2014) 14 IJDL 199.

${ }^{120}$ Downer et al, 'Evaluation of Acas Early Conciliation 2015', above n 85, at 69.

${ }^{121} \mathrm{Ibid}$, at 6,69 .

${ }^{122}$ Ibid, at 6.

${ }^{123} \mathrm{M}$ Downer et al, Evaluation of Acas Conciliation in Employment Tribunal Applications 2016, Research Paper 04/16, 2016, at 61.

${ }^{124}$ Ibid.

${ }^{125}$ C Menkel-Meadow, 'Whose Dispute is it Anyway? A Philosophical and Democratic Defense of Settlement (in Some Cases)' (1995) 83 Geo LJ 2663 at 2689.

${ }^{126}$ Ibid 2669-70.
} 
experience with the respondent can be enough to remedy the discrimination. ${ }^{127}$ Devereux writes that one of the anticipated advantages of using conciliation to resolve discrimination claims is that it would 'encourage thought about human rights and not exacerbate the relational problems at the root of the individual problem. ' ${ }^{28}$ In their study of changes to the AHRC's conciliation process, Raymond and Georgalis found a greater understanding of the conciliation process and a high satisfaction with settlement terms amongst participants. ${ }^{129}$ Similarly employees and employers who were party to a race discrimination claim at Acas reported a positive view of the conciliation process (even if they were not happy with the outcome) when they felt that the conciliator had listened to them and responded to their experience. ${ }^{130}$ Thus, focusing too narrowly on the material results achieved through conciliation may undersell the impact of ADR for both claimants and respondents; it is also important to acknowledge how empowering participating in the process, being in control of it and the outcome, can be.

\section{E Power Imbalances}

For Thornton, the employment relationship is a paradigmatic case of inequality of bargaining power. ${ }^{131}$ Employers have power derived from their access to information, documents and witnesses, as well as structural ideologies that uphold their power. ${ }^{132}$ Of course, the employment relationship and the power disparities embedded within it vary according to such things as the size of the employer, the skills of the employee, any collective presence, access to representation and competition in the marketplace. The claimant's own attributes may also contribute to the imbalance in power, including their gender, sexual orientation, race, age, language skills and disability. ${ }^{133}$ For example, one of the concerns with using conciliation to resolve sexual harassment complaints is that this may reinforce gender related power imbalances or result in unequal outcomes if the conciliator does not address them. ${ }^{134}$ Power disparities may be exploited in conciliation, to achieve less desirable outcomes for complainants. Thornton cites the example of a pregnancy discrimination claimant, who initially sought $\$ 1000$ in compensation (the equivalent of two months' salary), but accepted a letter of apology at settlement. ${ }^{135}$ Thus, conciliation may both cloak power disparities, and prevent public scrutiny of inequality. ${ }^{136}$

It is arguably not the role of ADR to address power imbalances: as Dickens notes, conciliation as it is currently framed is not concerned with the quality of settlements achieved, or the extent to which negotiated outcomes support or undermine social objectives: ${ }^{137}$ assessments of ADR's 'success' do not consider the settlements

\footnotetext{
${ }^{127}$ Allen, 'Behind the Conciliation Doors', above n 7, at 790.

${ }^{128}$ Devereux, above $\mathrm{n} 38$, at 283.

${ }^{129}$ Raymond and Georgalis, above $\mathrm{n} 97$.

${ }^{130} \mathrm{M}$ Hudson et al, above $\mathrm{n} 14$, at 74.

131 Thornton, 'Equivocations of Conciliation', above n 10, at 743.

132 Ibid.

${ }^{133}$ Ibid.

${ }^{134} \mathrm{~J}$ Davis and A Markman, Behind Closed Doors: Approaches to Resolving Complaints of Sexual

Harassment in Employment, Australian Human Rights Commission, 2004, at $<$ https://www.humanrights.gov.au/our-work/complaint-information-service/publications/behindclosed-doors-approaches-resolving $>$ (accessed 11 September 2017).

135 Thornton, 'Equivocations of Conciliation', above n 10, at 742.

${ }^{136}$ Ibid.

${ }^{137}$ Dickens, above 6, at p 38 .
} 
achieved. For Dickens, there appears to be a conflict between the search for a compromise, which lies at the heart of conciliation, and the pursuit of rights: ${ }^{138}$ conciliation risks recasting injustice as a form of disagreement between private parties, and can compound unlawful behaviour. ${ }^{139}$ For vulnerable claimants in Busby and McDermont's study, Acas's prioritisation of settlement was felt as a pressure to settle, and a lack of interest in the merits of their case. ${ }^{140}$

The impact of having access to legal advice and resources is also difficult for an impartial third party to address. In the UK, employers are significantly more likely to have legal representation in conciliation than claimants, increasing the power disparity between the parties. Unfortunately, the first year statistics did not analyse whether having legal representation influenced the outcome of conciliation, though it appears that employers without representation were more likely to reach a settlement. ${ }^{141}$

\section{F Lack of Jurisprudence}

A final criticism of ADR relates to its outcome - if ADR is successful and the parties settle their dispute, then the matter ends. If the facts of the case are novel or it would raise issues that would challenge accepted legal principles, this will not be tested and the law will remain unaffected. ${ }^{142}$ This may not be a concern if settlement is not the norm and courts are deciding a regular flow of cases or if the law is sufficiently developed and settled. In Australia this is not the case. Despite having antidiscrimination laws for over 40 years, there is a remarkably small body of discrimination case law. Most of it favours employers and there are principles that remain untested. For example, the High Court has only considered the rights and obligations that arise under anti-discrimination laws in the context of employment in three cases: ${ }^{143}$ two were about indirect sex discrimination, the other was about direct impairment discrimination.

The UK has not experienced the same dearth of case law, though the number of ET claims dropped dramatically during the period in which fees were charged. Further, the proportion of unsuccessful ET claims was consistently higher while fees were being charged, indicating that fees were more likely to be deterring meritorious claims than unmeritorious ones. ${ }^{144}$ This trend will likely self-correct now that the fees regime has been found to be unlawful. ET decisions have traditionally not been reported, which makes it difficult to track how discrimination cases are being decided. From 9 February 2017, however, ET decisions have been made available online. This will

\footnotetext{
138 Ibid.

139 Ibid.

${ }^{140}$ Busby and McDermont, above n 15, at 182.

${ }^{141}$ Downer et al, 'Evaluation of Acas Early Conciliation 2015', above n 85, at 68.

${ }^{142}$ When ADR began to proliferate, Fiss identified this as being a reason to not be in favour of settling cases: Fiss, above n 108.

${ }^{143}$ Australian Iron \& Steel Pty Ltd v Banovic (1989) 168 CLR 165; 89 ALR 1; [1989] HCA 56; Xv Commonwealth (1999) 200 CLR 177; 59 ALD 321; [1999] HCA 63; New South Wales v Amery (2006) 230 CLR 174; 226 ALR 196; [2006] HCA 14. Most of the discrimination claims that have reached the High Court have challenged the constitutionality of the laws and have not considered the substance of the law (see, eg, Ansett Transport Industries (Operations) Pty Ltd v Wardley (1980) 142 CLR 237; 28 ALR 449). It is noted that the High Court also considered age discrimination in Qantas Airways Ltd $v$ Christie (1998) 193 CLR 280; 152 ALR 365; [1998] HCA 18 but that claim arose under s 170DF of the Industrial Relations Act 1988 (Cth), not an anti-discrimination statute.

${ }^{144} R$ (Unison) v Lord Chancellor [2017] 3 WLR 409; [2017] UKSC 51 at [57].
} 
significantly increase the accessibility of future decisions, and allow deeper scrutiny of the emerging case law.

The lack of decided cases in Australia poses a problem for potential claimants, their advisers and equal opportunity agencies because they do not have any guidance about how the court will interpret particular aspects of the law. A lack of jurisprudence also raises challenges for employers and their advisers, who may not know what compliance entails. It may deter both sides from pursuing their claim to court, for fear of losing the claim. By contrast, participants in race discrimination claims conciliated by Acas reported that the conciliator's discussion of case law was valuable in helping them determine whether or not to proceed. ${ }^{145}$ There is an information gap, however, in Australia which makes this task difficult.

Without being grounded in some rule-based system (and, subsequently, the rule of law), ADR risks devolving into 'anarchistic manipulations of situational morality "whatever works", which undermines legal and societal stability. ${ }^{146}$ MacDermott therefore argues that litigated outcomes are essential to the regulatory framework as they establish 'the parameters within which parties can seek to negotiate an outcome.' ${ }^{147}$

Finally, a lack of case law can undermine the potential of discrimination law to achieve social change: Clarke and Davies argue that discrimination claims are one area in which mediation might not be appropriate, as 'without public scrutiny and awareness there will be no attempt to reform ... entrenched discrimination'. ${ }^{148}$ Thus, the interests of the community in addressing discrimination may outweigh individual interests in settlement: ${ }^{149}$ in these cases, confidential ADR is not the correct process. The risk, however, is that case law has not always been a positive development in the context of discrimination claims ${ }^{150}$ and it can take time for courts to catch up to contemporary standards. What this reinforces is the need for broader reform to the regulatory framework, which we discuss below.

\section{Discussion and conclusion}

The use of ADR to resolve discrimination complaints in Australia and the UK, with its focus on confidential settlement, highlights problems related to secrecy, a lack of systemic outcomes, power imbalances, and a lack of jurisprudence. This is particularly concerning in Australia, where a dearth of case law could seriously undermine the objectives of discrimination law.

\footnotetext{
${ }^{145}$ M Hudson et al, above $\mathrm{n} 14$, at 68 .

146 Wolfe, above n 17, at 794.

${ }^{147}$ T MacDermott, 'The Collective Dimension of Federal Anti-discrimination Proceedings in Australia: Shifting the Burden from Individual Litigants' (2018) 18 IJDL 22.

${ }^{148}$ Clarke and Davies, above n 11, at 76-7.

149 Ibid.

${ }^{150}$ In Australia see eg Purvis v New South Wales (Department of Education and Training) (2003) 217 CLR 92; 202 ALD 570; [2003] HCA 62 in which the High Court took a restrictive approach to the interpretation of 'disability'. Fortunately, in this instance, the legislature responded some years later and amended the Disability Discrimination Act 1992 (Cth) to alleviate this problem (see Disability Discrimination and other Human Rights Legislation Amendment Act 2009 (Cth)) but there was no scope for the AHRC to achieve the same through litigation. Cf the Disability Rights Commission, discussed below.
} 
That is not to suggest that every case should be litigated. As this article has shown, there are strong reasons to be in favour of using in ADR to resolve workplace discrimination claims rather than the courts. However, ADR needs to be part of a range of mechanisms for enforcing the law. Litigated outcomes are an essential part of that framework. Thus, it is necessary to shift away from the current reliance on ADR and address impediments to litigating claims to build a body of case law, particularly in Australia.

With this in mind, the key regulatory weakness in Australian discrimination law is that it relies on the individual for enforcement; there is no scope for the equal opportunity agencies to enforce the law. ${ }^{151}$ Smith writes:

The absence of an enforcement agency as a public prosecutor serves to characterise discrimination as merely a private matter and one that harms only the victim, not society at large ... Limiting enforcement to victims also means that unlawful discrimination will go unaddressed unless there is a victim who is willing and able to complain. ${ }^{152}$

There is much, therefore, that Australian discrimination law could learn from the UK and Australian industrial law in this regard. In the UK, since the introduction of antidiscrimination law, statutory agencies ${ }^{153}$ have had the power to enforce the law. They have done so primarily by intervening in relevant matters and by providing financial assistance to employees so they can pursue their claim or taking claims on their behalf. They also have the power to launch an investigation into a non-compliant employer and issue compliance notices if appropriate, though have not used this as frequently or effectively. ${ }^{154}$

Of these powers, the Australian equal opportunity agencies only possess the intervention function. They use this function to intervene in both discrimination matters and matters which raise issues relating to discrimination and equality in which they can offer the court their expertise and guidance about how the law should be interpreted. For example, the Victorian Equal Opportunity and Human Rights Commission recently intervened in an application for an exemption under the Equal

\footnotetext{
${ }^{151}$ This gap has been identified by other scholars and explored in depth elsewhere. See B Smith, 'Not the Baby and the Bathwater: Regulatory Reform for Equality Laws to Address Work-Family Conflict' (2006) 28 Syd LR 689; B Smith, 'It's About Time - For a New Regulatory Approach to Equality' (2008) 36 FL Rev 117; D Allen, 'Barking and Biting - the Equal Opportunity Commission as an Enforcement Agency' (2016) 44 FL Rev 311; T MacDermott, above n 147.

${ }^{152}$ Smith, 'It's About Time', above n 151.

${ }^{153}$ The Equality and Human Rights Commission commenced operation in October 2007, replacing the Equal Opportunities Commission, Commission for Racial Equality and Disability Rights Commission which had been in existence since 1975, 1977 and 2000 respectively.

${ }^{154}$ For detailed discussion of these powers see N O'Brien, 'The GB Disability Rights Commission and Strategic Law Enforcement: Transcending the Common Law Mind' in A Lawson and C Gooding (Eds), Disability Rights in Europe: from Theory to Practice, Hart Publishing, Oxford, 2005, p 249; C O'Cinneide, 'The Commission for Equality and Human Rights: A New Institution for New and Uncertain Times' (2007) 36 ILJ 141; G Appleby and E Ellis, 'Formal Investigations: The Commission for Racial Equality and the Equal Opportunities Commission as Law Enforcement Agencies' [1984] PL 236; D Allen, 'Strategic Enforcement of Anti-Discrimination Law: A New Role for Australia's Equality Commissions' (2010) 36 Mon LR 105; Allen, above n 151.
} 
Opportunity Act 2010 (Vic). ${ }^{155}$ The Commission made submissions about what is required to establish that conduct is a special measure for the purposes of $\mathrm{s} 12$ of the Act. The tribunal's reasoning was influenced by the Commission's submissions, and the decision clarified the meaning of 'special measures' under the Act. This has meant that fewer claimants have had to seek an exemption, because it is now clear what conduct is covered by s 12 . However, the effectiveness of this function relies on appropriate matters reaching the courts and the agency having the resources to appear, so it needs to be one of a range of powers available to the agency, as it is in the UK.

Australian legislatures have been reluctant to give equal opportunity agencies the power to investigate non-compliant organisations. These powers were originally introduced in Victoria when the Equal Opportunity Act 2010 (Vic) was passed, but they were subsequently removed with a change in government before the Act came into force. ${ }^{156}$ Commentators like Smith have argued that a change in regulatory structure, to allow equal opportunity agencies to investigate non-compliance, would increase voluntary compliance by employers for fear of a 'big stick' being levelled against them. ${ }^{157}$

Since Smith made these comments, s 351 of the Fair Work Act 2009 (Cth) has come into force. It prohibits adverse action (which includes dismissal and discrimination) on a range of attributes including race, sex, age and disability and, unlike antidiscrimination law, it does not rely on the employee for enforcement. The Fair Work Ombudsman ('FWO') can enforce s $351^{158}$ and it does so in a manner similar to that contemplated by Smith. The FWO can investigate whether there has been a breach of 351 and, if it reasonably believes that a person has contravened the Act, it may accept enforceable undertakings from the employer ${ }^{159}$ or pursue litigation and seek the imposition of a civil penalty. ${ }^{160}$ Unlike the equal opportunity agencies, the FWO is not responsible for receiving discrimination claims; it focuses entirely on enforcement. Although the FWO pursued a number of discrimination claims between 2011-2014 ${ }^{161}$ it has been less active in this area more recently. ${ }^{162}$ The FWO and the enforcement of industrial law offers a model for strengthening the enforcement of discrimination law in Australia.

By contrast, the primary way the UK agencies have enforced the law and influenced its development is through the power to provide assistance to claimants, both financial and otherwise. The agencies become aware of cases they may want to support through their networks of lawyers and by way of claimants who apply for financial assistance. In her examination of how the agencies have used this function, Allen showed that they used it to develop the law by testing new principles, achieving systemic

\footnotetext{
155 Waite Group [2016] VCAT 1258 (28 July 2016).

${ }^{156} \mathrm{Cf}$ the Fair Work Ombudsman which can launch investigations and pursue compliance, much like ASIC and the ACCC.

157 Smith, 'Not the Baby and the Bathwater', above n 151, at 706.

${ }^{158}$ Section 539. Industrial associations can also bring claims on behalf of their members.

${ }^{159}$ FWA s 715.

${ }^{160}$ FWA, ss 539 (Item 11), 546.

${ }^{161}$ See eg Fair Work Ombudsman v Tiger Telco Pty Ltd (in liq) [2012] FCA 479 (9 May 2012); Fair

Work Ombudsman v Rocky Holdings Pty Ltd (2013) 279 FLR 412; [2013] FCCA 1549.

162 It only litigated one discrimination matter in 2017 (Fair Work Ombudsman v Yenida Pty Ltd (2017)

276 IR 108; [2017] FCCA 2299) and none in the 2015-16 financial year, nor did it enter into any enforceable undertakings in relation to discrimination claims in that period.
} 
remedies, and challenging unfavourable decisions. ${ }^{163}$ For example, when a Court of Appeal decision lowered the threshold for the justification defence in a disability discrimination claim, the then Disability Rights Commission pursued a range of cases chosen to moderate the impact of the decision. This led ultimately to the agency supporting the first disability discrimination claim to reach the House of Lords, ${ }^{164}$ which limited the effect of the Court of Appeal's decision. ${ }^{165}$ Allen argues that in Australia there is great scope for the agencies to litigate strategically in the same way, by targeting unfavourable decisions and building a coherent body of case law. ${ }^{166} \mathrm{In}$ turn, we suggest that this would influence settlement outcomes and provide guidance to all participants in the ADR process about how a potential claim may be decided. For the UK going forward, the challenge will be to maintain the successes of the statutory agencies, particularly in the face of substantial budget cuts to the EHRC and an increased focus on ADR. Similarly, for the FWO, a key challenge relates to keeping discrimination and adverse action as priorities for enforcement activity, in the face of many competing priorities.

While a statutory enforcement process is a necessary complement to individual enforcement, it is also timely to review the role of ADR in resolving employment discrimination complaints. The prevalence of significant power differentials, and the importance of publicity and public messaging in addressing discrimination, mean ADR may be inappropriate in many disputes. To ensure ADR is appropriate, we propose four key areas in which is it necessary to review the current regulatory framework.

First, serious thought must be given to making ADR a voluntary complement to litigation, rather than a system devoid of choice and voluntariness. ${ }^{167}$ ADR was not intended as a compulsory system that overrides or replaces court-based litigation: it was intended as a voluntary complement to existing legal processes, which offers a choice to litigants. ${ }^{168}$ If this choice and voluntariness is removed, the validity of ADR may be significantly undermined. While mandatory mediation offers substantial benefits in efficiency and cost savings for both courts and parties, ${ }^{169}$ this is unlikely to offset the loss of autonomy and control inherent in forced ADR. ${ }^{170}$ Thus, given the risks inherent in mandatory conciliation, and ADR more generally, it is questionable whether the Australian model of compulsory conciliation for discrimination claims is desirable. Further, this calls into question the 'compulsory notification' model adopted in the UK, which starts to resemble compulsory conciliation for some claimants who misunderstand the distinction between notification and conciliation.

\footnotetext{
${ }^{163}$ She argued that they could then assume some of the characteristics of Galanter's 'repeat players': D Allen, 'Strategic Enforcement', above n 154, at 116-23.

164 Archibald v Fife Council [2004] 4 All ER 303; [2004] IRLR 651.

165 See discussed in Allen, 'Strategic Enforcement', above n 154, at 133.

${ }^{166}$ Ibid, at 125.

${ }^{167}$ See similarly A M Leonard and R Hunter, 'Sex Discrimination and Alternative Dispute Resolution: British Proposals in the Light of International Experience' [1997] PL 298 at 311.

${ }^{168}$ Gruin, above n 27, at 208-9; C Green, 'ADR: Where did the "Alternative" go? Why Mediation should not be a Mandatory Step in the Litigation Process' (2010) 12(3) ADR Bulletin art 2.

${ }^{169}$ Mahoney, above $\mathrm{n} 12$, at 120-2.

${ }^{170} \mathrm{Cf}$ ibid, at 123-4. Though, of course, mandatory ADR only requires participation, it does not specify the outcome. Thus, some control and autonomy is maintained: see further M Hanks, 'Perspectives on Mandatory Mediation' (2012) 35 UNSWLJ 929 at 949.
} 
Second, it is timely to reconsider the current over-dependence on confidential ADR processes and outcomes. Confidentiality is simultaneously the strongest asset of conciliation - promoting open dialogue, early resolution of disputes and full participation of the parties - and its strongest drawback, preventing nuanced consideration of the outcomes and processes adopted, the prevalence of power disparities that potentially undermine the process, and scrutiny of the ability of ADR to achieve the public and private aims of discrimination law. To address this tension, it is necessary for the bodies conducting ADR to publish fulsome, timely and detailed de-identified information about the claims, processes, and outcomes achieved. This minimum level of transparency is a necessary check on the use of ADR in the context of discrimination claims. It will help fulfill discrimination law's educative function, offer guidance to potential claimants and their representatives about anticipated outcomes, and offer respondents guidance as to what compliance entails. Achieving this level of effective transparency in the ADR process will be a challenge facing bodies in both the UK and Australia in years to come. Going further, then, Leonard and Hunter argue that privacy and confidentiality should apply to the mediation process, but not to mediated settlements, where there is less justification for confidentiality. ${ }^{171}$ To promote public awareness and discussion of discrimination, Leonard and Hunter suggest adopting a presumption that mediated settlements become a matter of public record, and only remain confidential if both parties wish to keep the outcome private. ${ }^{172}$ This would resolve many of the difficulties associated with the confidentiality of ADR, while still allowing for open dialogue and full participation.

Third, the risks of ADR could be better managed by empowering the bodies conducting ADR processes to refer certain matters to court where the issues raised are of potential legal or systemic significance. This would enable problematic aspects of the law to be tested in a public forum, and help to develop jurisprudence in areas of need. For this to be effective, claimants in these cases would need to be supported in putting forward their claim, either through legal aid or the intervention of equal opportunity agencies, to ensure that courts have enough information to grapple with the complex issues at hand. Again, this would help to increase transparency in matters of significance, and would help build a solid body of precedent as a background against which ADR could occur. This would likely lead to better ADR processes and outcomes for claimants more generally.

Fourth, it may be useful to review the approach to conciliation adopted by equal opportunity agencies and statutory bodies. Discrimination complaints are not just about the individual dispute: they often reflect systemic patterns of discrimination and exclusion, which - under the current system of enforcement - are only regularly addressed through individual complaints. A move towards committed conciliation, where conciliation is designed to achieve settlements consistent with certain substantive outcomes and social objectives, might address some of the limitations of ADR in the context of discrimination. ${ }^{173}$ Similarly, Leonard and Hunter argue for 'rights-based mediation', which 'prioritises legal rights and the elimination of discrimination', and intervenes in the power imbalance between parties, with a view

\footnotetext{
${ }^{171}$ Leonard and Hunter, above n 167, at 313.

172 Ibid, at 314.

${ }^{173}$ Dickens, above n 6, at p 38.
} 
to the parties agreeing a resolution that is broadly in line with their legal rights. ${ }^{174}$ Likewise, Poole argues that the conciliator could facilitate systemic outcomes by taking an active role in the dispute by using rights and interest based interventions to guide the parties to reach an outcome that is appropriate to them as individuals and to society as a whole. ${ }^{175}$ Through the ADR process, equal opportunity agencies and statutory bodies can take a proactive role in promoting social objectives, including by suggesting systemic changes to claimants and respondents, prioritising rights, and questioning behaviours that potentially replicate discrimination. While this challenges the dominant view of conciliators as 'neutral' or 'impartial', it recognises their fundamental role in shaping issues and outcomes. ${ }^{176}$ Indeed, it is questionable whether conciliators can or should be impartial: ${ }^{177}$ some claimants in race discrimination conciliations desired that conciliators take a more proactive role. ${ }^{178}$ Taking on this proactive role will require skilled and well-trained conciliators and mediators, ${ }^{179}$ who are able to commit time and energy to resolving individual disputes in a way that is consistent with social objectives. Again, this will be a substantial practical challenge for under-resourced and over-burdened equal opportunity agencies and statutory bodies in the years to come.

\footnotetext{
${ }^{174}$ Leonard and Hunter, above n 167, at 311 . This approach was used successfully by the UK Disability Rights Commission, though only for non-employment claims. See further Allen, 'Against Settlement?', above $\mathrm{n}$ 26, from 204.

${ }^{175}$ R Poole, 'Facilitating Systemic Outcomes through Anti-discrimination Conciliation and the Role of the Conciliator in this Quest' (2016) 27 ADJR 49 at 57.

${ }^{176}$ Busby and McDermont, above $\mathrm{n} 14$, at 180-1.

${ }^{177}$ Ibid, at 180.

${ }^{178}$ Hudson et al, above n 14, at 12 .

${ }^{179}$ Leonard and Hunter, above n 167, at 311, 313.
} 